\title{
THE ARAGONESE CASTLE OF PIAZZA ARMERINA, SICILY: NEW SURVEYS FOR THE CONSERVATION AND THE VALORISATION OF A CULTURAL RESOURCE
}

\author{
A. Versaci ${ }^{1}$, A. Cardaci ${ }^{2}$, L.R. Fauzìa ${ }^{1}$, M. Russo ${ }^{1}$ \\ 'Faculty of Engineering and Architecture, University of Enna 'Kore', Italy \\ (antonella.versaci, luca.fauzia, michele.russo)@unikore.it \\ ${ }^{2}$ Dept. Engineering and Applied Sciences, University of Bergamo, Italy - alessio.cardaci@unibg.it
}

KEY WORDS: Integrated 3D survey, Conservation, Restoration, Reuse, Piazza Armerina, Sicily.

\begin{abstract}
:
Sicily owns a vast heritage consisting of manors, strongholds, coastal towers and city fortifications that reflect its long history and strategic role in the Mediterranean Sea. Most of these assets are now in poor condition and abandoned, affected by both aging and the lack of preservation and maintenance activities. Their knowledge is often incomplete because of a lack of archival sources and the quasi-absence of accurate surveys and stratigraphic analyses. A systematic research programme on the most important castles in central Sicily, was then launched. In this context, this paper presents the case study of the Aragonese castle in Piazza Armerina. It shows the first results of a multidisciplinary study based on the integrated use of technologies for three-dimensional survey and supported by new critical interpretations of the morphological and material peculiarities of such an important cultural good. An operational practice aimed at correctly orienting future restoration and reuse activities, based on both scientific criteria and respectful approach to the monument.
\end{abstract}

\section{INTRODUCTION}

Sicily has a large number of castles of great historical and artistic importance. They are the tangible sign - although sometimes in an advanced state of ruin - of important pages in the history of the island. Today, often immersed in urban and peri-urban contexts of much lower quality, they testify to its complex relationship with the sea, furrowed over time by numerous invaders.

The few available chronicles mention, during the Byzantine domination, the presence of kástra (cities and fortified towns), rural towers and walled farms: a network on which the fortified system of the Islamic Siqilliyya would be later structured (827-902). However, it is during the Norman conquest (1061-1091) that the Sicilian territory is enriched with solid fortified places - initially, counter-castles or campaign-castes - aimed at halting the advance of the enemies. Even after the total occupation of Sicily by the Normans, the building of defence structures continue. They erect several castra, which will later belong to the royal domain. During the reign of the kings of Altavilla, the first administrative structure of the state-owned castles gradually take shape and is perfected during the reign of Frederick II, Charles of Anjou and then through the Aragonese period which develops after the Sicilian Vespers (1282).

Unlike central-northern Italy - already invested by those new political apparatuses that will lead to the birth of the municipalities and lordships, and therefore to the abandonment of passive defence - Sicily in the second half of the $14^{\text {th }}$ century is torn between feudal dominations. Fortifications continue to be raised in areas topographically favourable from a tactical point of view. The State castles - ruled by a captain and a castellan - become the local hubs of a system of power on constant alert (Maurici 2020). They base safety and inviolability on natural inaccessibility. Therefore, once their original intended use ceased and precisely because of their 'aristocratic loneliness', they will suffer the consequences of an unavoidable decline.

Although attacked and afflicted over time by numerous cataclysms, wars, raids, massacres, but also neglect and indifference, this vast legacy still characterizes the landscape, giving proof of an uncommon resilience. Insufficiently known and safeguarded - despite the numerous attempts made, alas, not always in a coordinated and/or coherent way - it deserves greater attention from local and regional governments.

In recent years there has been a renewed interest in this heritage and a series of non-marginal recovery interventions have been made. Nevertheless, in many other cases, its survival is essentially entrusted to voluntary cultural associations or to the few informed private owners who strive to both preserve and reuse it sustainably.

This is for example the case of the castle of Piazza Armerina, a town not far from Enna, well-known for the UNESCO World Heritage site of the Villa del Casale (1997). The manor, one of the major examples of the Aragonese period, is part of a building complex of great value. The urban fabric that over time has gradually and spontaneously surrounded it, although today altered by several replacements, still has the original textures legible, so offering a globally 'intact' image of the ancient layout. A valid example of military architecture, the castle is, in particular, an essential document for local and regional culture. Unfortunately, it has been plagued by numerous vicissitudes and by the needs imposed by a readjustment to a prison dating back to the early decades of the $19^{\text {th }}$ century, which made a radical transformation of the internal and external environments. Finally, it has suffered further impoverishment due to the lack of the necessary conservation activities for financial reasons, among others.

It was only during the past five years that the new private owner decided to undertake new studies for the restoration and functional recovery of the structure. But the castle was still to be investigated in many respects: barely visible traces seemed to hide constructive vicissitudes to no one so far known, but essential in terms of historical knowledge not limited to the artefact but potentially useful to elucidate important steps of the town's history. For ten years already engaged in systematic research aimed at identifying, evaluating, and documenting Central Sicily's fortified sites (Versaci et al., 2020), the authors of this paper, then undertook a survey campaign of Piazza Armerina's castle based on the integration of innovative technologies for $3 \mathrm{D}$ survey and 
mapping. The new study aimed to document the fortress very precisely from a metric point of view, making a substantial correction compared to the few surveys drawn up previously. It has also, and above all, set out to make readable the stratifications recently brought to light; to compare them with $19^{\text {th }}$-century documentary data of great interest and already known in the literature (Nigrelli 1983) but inexplicably later fallen into oblivion. Tangible signs of interesting pre-existences now highlighted and clarified by representation techniques, specifically conceived to bring out the morphological and material particularities and the state of conservation of such a multi-layered cultural object. It is a preliminary work of understanding and critical interpretation, intended as the essential prerequisite for the adoption of quality measures aimed at the conservation, restoration, (re)use and enhancement of a common good.

\section{THE CASTLE OF PIAZZA ARMERINA}

\subsection{The role of the manor in the urban context}

The Aragonese castle of Piazza Armerina is located at the south end of the Mira hill. The old district of Monte - the nucleus of the Norman reconstruction of the city, characterized by a rigid structure in chevrons - occupies the western side of this promontory. In the eastern part, is the Borgo di Piazza, also known as the Castellina district . It develops with a more instinctive urban layout made by buildings adapted to the orography of the hill. Two connected urban voids - respectively piazza Castello, which hosts the baroque architecture of the Velardita and Mandrascate palaces, and the so-called piano carcere on which the $17^{\text {th }}$-century church of Santa Maria della Neve stands - border the north and west fronts of the manor. Its meridional side looks out onto the valley of a tributary of the Gela River.

The location on a dominant hill suggests that the natural inaccessibility of the slope assured the defensive function on this front. This feature also indicates that the structure had in the past a controlling and watchful position on the underlying territory. The post-unification land registry shows that the south coast remained completely unedited until the end of the $19^{\text {th }}$ century. However, during the following century, the establishment of terraces allowed the construction of groups of townhouses.

The west side of the castle faces rather the ancient Jesuit college. On this front too, the signs of urban changes attributable to the early decades of the $20^{\text {th }}$ century are visible. Historical land registers shows that, until the end of the $19^{\text {th }}$ century, the road connecting the Cathedral square and the castle was via Mandrascate and not the current via Floresta; an alley originally closed from the area of the convent of Sant'Agata.

The demolition of the convent started in the last decade of the $19^{\text {th }}$ century (Nigrelli, 2019). It created a new and more direct connection between the baroque acropolis of the city, rich in monuments located in both the cathedral and castle squares. Another sign of this transformation can also be found in the ancient masonry at the basement of the castle, which, on the afore-mentioned slope, presents a particular curvature originally intended to laterally delimit the terminal part of via Mandrascate.

\section{$2.2 \quad$ Historical background}

Historians affirm that the foundation of the castle dates back to 1392 and is due to Martin the Younger, King of Sicily, who landed on the island together with his father Martin I of Aragon to defend the interests of the crown. Its construction was required to give the city a new power structure, better adapted to the objectives and needs of the Spanish government. The old manor, located at the opposite end, in the northern area of ancient Platia, was no longer able to respond to the vehement demands of repression against the exponents of the major feudal families of the island that they controlled as vicars (Fig. 1).

The structure was therefore built on the site of an ancient Franciscan monastery "to better fortify the summit of the South, much more important than the first fortress" (Bonifazio, 1950, 6). The brothers were in exchange authorized to move to the old castle north of the town "which they immediately converted into a religious house" (Roccella, 1890, III, 253). This was made possible thanks to the large amounts of money assigned for this purpose by King Martin I and Queen Maria, together with the annual sum of three gold coins for their livelihood (Amico, 1859, 354).

The State Castle, the designation of its castellanum and that of the chaplain, were reserved to the king (Bresc \& Maurici 2009). In 1396, he first appointed to this role the Catalan Giovanni Suriano, Knight of the Holy Sepulchre and prior of the church of Sant'Andrea, who had 12 sergeants under its command. Documentary sources attest that by decree of November 5, 1438, Alfonso V, King of Aragon (1416-58) and King of Naples (as Alfonso I, 1442-58), granted the Castellania of Piazza to Alfonso de Cardenas, his adviser as well as that of his successor, the King Ferdinand. This concession was confirmed in 1488. However, later the heirs, considering themselves invested in the fiefdom of the castle property, garrisoned it by soldiers by them chosen to collect the taxes imposed on the citizens (Roccella, 1890, III, 253). The castle was then ignored by historians for over four cen-
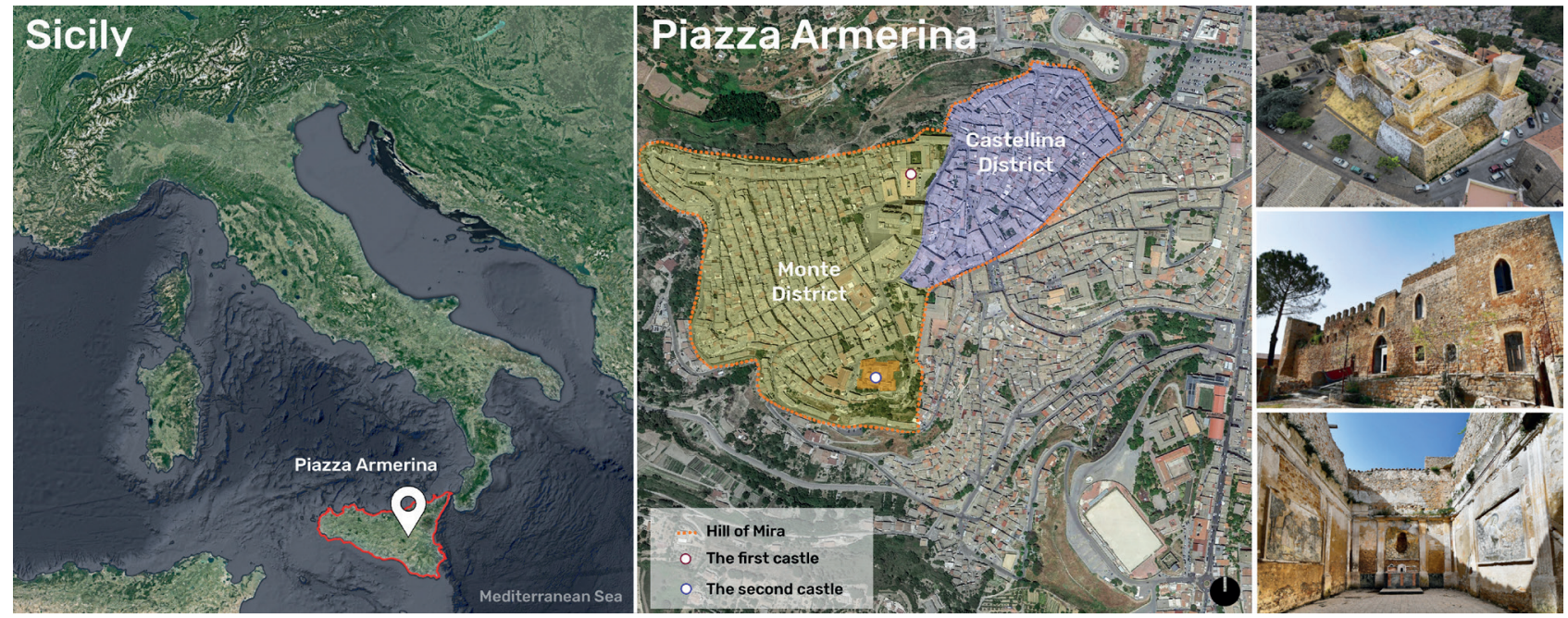

Figure 1. The town of Piazza Armerina, Sicily and its relationship with the Aragonese castle 
turies: only from 1812 (the year in which, with the promulgation of the Constitution, the Parliament abolished feudalism leading to an administrative and financial reform of the Kingdom of Sicily) onwards, it is possible to trace new events. In the same year, the structure become a public property and is used as a prison. The document drawn up in 1881 by the engineer Luigi Pappalardo, inspector of monuments and antiquity excavations in the Caltanissetta district, shows the first interesting description of the manor. The witty and competent Pappalardo starts an excavation campaign in the valley of the Gela river and discovers the first remains of what would become one of the most symbolic monuments of the region: the aforementioned Villa Romana del Casale. During the same mission, he visits the castle and mentions the presence of a chapel "in the right wall of which, there are traces of a pointed archivolt, but in which, however, the enclosed space is covered by special masonry, later performed there" (Pappalardo 1882). The chronicle provides other precise indications on architectural elements - today unrecognizable - and as many important research clues for the restoration. Brought to light in 1983 by the historian Ignazio Nigrelli, the report now preserved in the Central Archives of the State of Rome among the documents of the Directorate-General for Antiquities and Fine Arts will be ignored by subsequent studies and conservation/reuse projects. Research carried out in the State Archives of Enna confirms that the castle, while maintaining its prison function, returned to being, at the end of the $19^{\text {th }}$ century, private property and, specifically, of the general Francesco Pignatelli, prince of Strongoli, husband of Maria Giuseppa de Cardenas. The absence of progeny means that the house titles of Cardenas pass to the descendants of his aunt Giovanna, wife of Antonio II Spinelli, prince of Scalea. The Spinellis, therefore, succeeded the heraldic patrimony of the Cardenas family, inheriting, among other things, the castle.

Subject to a protective restriction in July 1913, the asset was finally purchased in 1974 by a local art collector and remained unused ever since. In 1980, an initial hypothesis of conservation by architects Rosa Oliva and Francesco La Morella was studied but never carried out. Between 2002 and 2004, architect Cesare Sposito conceived a second project to restore, consolidate and re-functionalise it as an exhibition space. However, only few fragmentary restorations on the external part have been performed. For a long time, the castle remained abandoned, improperly exploited as a deposit of building material. Over the years, it 'regressed' to the thankless rank of a real 'forest', due to the spontaneous grassy formations that for a long time covered its mighty walls, making it almost completely invisible.

Put up for sale in 2016 and despite the repeated trading proposals made to the regional public administrations, always refused for lack of funds, the manor was finally bought by a Sicilian entrepreneur who has lavish to ensure its due recovery. The new owner attempted to make the building safe. This allowed the use of part of it, with the subsequent occasional visit of tourists, researchers and citizens. Since the fall of 2019, the FAI - Fondo Ambiente Italiano (the National Trust for Italy) volunteers, as well as a committee composed of individuals and representatives of local cultural associations, turned the spotlight back on this prestigious heritage. Albeit severely slowed down by the COVID-19 pandemic, new studies have been carried out to implement the knowledge on the castle, alas sparse and never properly deepened.

\section{NEW STUDIES TO CREATE NEW KNOWLEDGE}

\subsection{A critical review of the old representations}

The existing documentation on the Aragonese castle is very lacking. In particular, iconographic sources are rare and limited to the modern era (Fig. 2). To date, there is no trace of images of the city dating back to the Middle Ages

The fortress's first illustrations are from the early $17^{\text {th }}$ century. In the three works of art known so far, it is depicted in the context of the urban fabric of Piazza Armerina. They are extra-moenia 'bird's eye views', reproduced from Borgo Casalotto, probably derived from the same viewpoint, perhaps, sketched by an antique traveller on the Grand Tour. The Cathedral, with the bell tower, but without the dome, appears in its transformation phase between the $16^{\text {th }}$ and $17^{\text {th }}$ centuries. This, together with the obvious historical dating, allows us to understand the role of the fort compared to the other edifices of the town.

The first - a painting entitled "Saints offering the city to the Madonna delle Grazie" by Paolo Piazza - is dated to 1612. The city appears on a small tray in the centre of the picture; it is granted by the patron saints as a gift to the Madonna to ensure her protection. The castle is painted with low sloped walls and high towers (three in number because the fourth is concealed by the dungeon). To the left is the ravelin, protected by a round tower. The second painting named "Sant'Andrea Avellino invoking the protection of the Virgin" was commissioned to Antonino Cinniardi in 1626 (but the first attestation dates back to 1641). Piazza Armerina, downright next to the holy and below Mary, is depicted with great care in its architecture. The castle seems to have a regular shape with four crenellated towers at the top (one of which, the dungeon, is taller and more imposing). There is also a second group of walls as well as the ravelin, with another lower and smaller tower. The connecting road - today, via Misericordia - going from the summit of the hill to the Mother Church, is clearly visible.

The third representation (1632) is a gold, silver and enamel medal by Camillo Barbavara. The high relief reproduces the fortress at the top of Mira hill, protected by mighty sloping walls. A low silhouette without towers is placed in the interior; the ravelin is represented here too. All views seem to point to a path to the east, along the steep slope of the mount: the only access to the impressive fortification. They underline the isolated character of the castle, which is independent and autonomous from the rest of the city, but, above all, unaffected by strong urbanisation.

The famous "The town and convent of Piazza" by the landscape painter Leitch William Leighton (etching by Allen James Baylie), although dating back to the second half of the $19^{\text {th }}$ century, does not document any change. Here, the castle stands imposing on

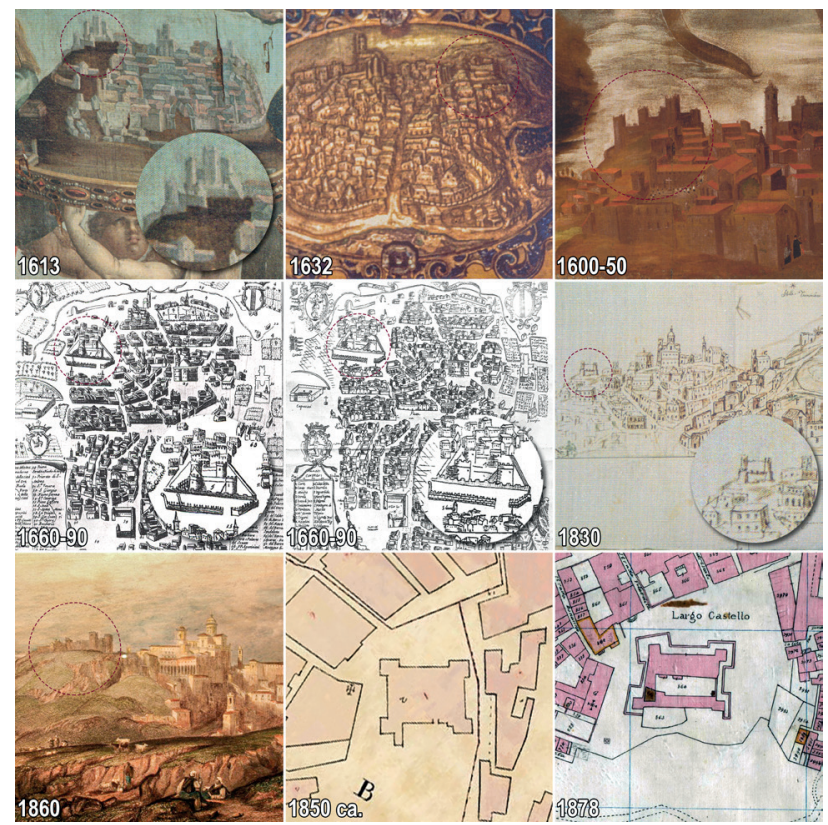

Figure 2. Historic iconography and early representations of the castle 
the top of the mountain and separated from the city, also due to the view from the west that hides the buildings and houses along the via Misericordia. It is perhaps an 'ideal' representation that tends to focus on the natural landscape of the inland areas of the island; the bare rock and the shepherds with the flocks of sheep in the foreground seem to confirm it.

All these views highlight the importance of the fortress within the town and its role in urban development; although they are rich in information, they reveal little or nothing about the forma urbis (Nigrelli, 2020). Furthermore, they are highly conditioned by the subjective interpretation of the creators, who may never have had a direct relationship with the city.

The first reliaable plan of Piazza Armerina - actually, a volumetric plan in oblique projection - is done by Paolo Petrini and dates back to the second half of the $18^{\text {th }}$ century. A second representation of it is also known, very similar to the first and perhaps a copy. Both the urban morphology and the hierarchy of public spaces are perfectly legible and the most important buildings and places in the city are listed. Special attention is paid to gardens, springs and waterways, churches and convents in the countryside. The castle is well described in terms of morphology and architectural details. Its quadrangular shape with the four towers and the sloping walls is evident as well as a second wall surrounding the ravelin on the western side. However, it appears without the squat tower, but displays a southern opening. Compared with the early views of the city, the fortress seems to have changed, particularly in the access, no longer from the escarpment. It can be observed that the east/southeast side is still clear of buildings and that the castle rises majestically at the top of the mountain.

The Bourbon land register (cadastre, 1837-1853) provides the first cartographic representation of Piazza Armerina. Drafted by the surveyor Benedetto Digaetano, although not very faithful, it represents blocks and public spaces; it does not illustrate the courtyards or provide information on the internal subdivision of buildings (Caruso \& Nobile, 2001). The castle is depicted in its actual rectangular shape with the four towers. There is no trace of the boundary walls and also the ravelin is missing rather in the representations of earlier centuries.

Between the end of the $19^{\text {th }}$ century and the beginning of the $20^{\text {th }}$ century, the transformation of the castle into prison required appropriate design for the project and the construction site. But, the documents and drawings related, although they may have existed, are now scattered.

\subsection{From contemporary surveys to new metric studies}

The first surveys of the fortress date from the end of the last century, after the dismission of the ancient prison. The precise measurements of the mansion were indeed necessary for the development of the 1980's restoration project. In this framework, the castle is represented through orthogonal projections at the scale of 1:100 and 1:200 (Fig. 3). Plans show the spaces and the thicknesses of its walls, the escarpments and the external walls; they indicate the trilaterations undertaken. This leads us to imagine that the measurements were carried out with the direct method through traditional measuring wheels and that the error compensation was made through the graphical method. No singular points with known coordinates - that could allow us to imagine the definition of a topographical control network - have been included. The georeferencing seems to have been done through the cadastral plans too.

Drawings of the façades are very accurate on materials and decay mapping but they are perhaps little verified in the metric and geometric aspects. They were based on eidotypes controlled by some points measured at the base. The survey was also used for the preparation of the second restoration project (2002-2004).
Drawings were enriched by further sections and adapted to the existing condition; however, they slavishly reproduce the previous measurements.

The castle has been the focus of renewed attention in recent years. Some Master theses in Architecture have been developed or are still in progress. While they explore the issue of the reuse of the ancient building, they do not give rise to new cognitive investigations, methodologically well-founded. These studies do little or nothing to improve information on the structure. They are not employing any new technology for metric and material comprehension, or at least they are not employing it with the necessary rigour. They merely re-use existing graphics, without carrying out the appropriate checks.

Aware of the need to provide instead for a new global and particular survey of the structure, the new research was conducted, both through the consolidated practice of integrated survey and the diagnostic investigation (Fig. 4). An integrated approach was followed to fill the gaps related to the knowledge and understanding of the building, as well as aimed at developing new archaeological excavation and stratigraphic analysis of the curtain walls. The investigative campaign began with 'intimate and direct' contact with the monument, through several inspections. This was then done using instruments based on active (3D laser scanning)

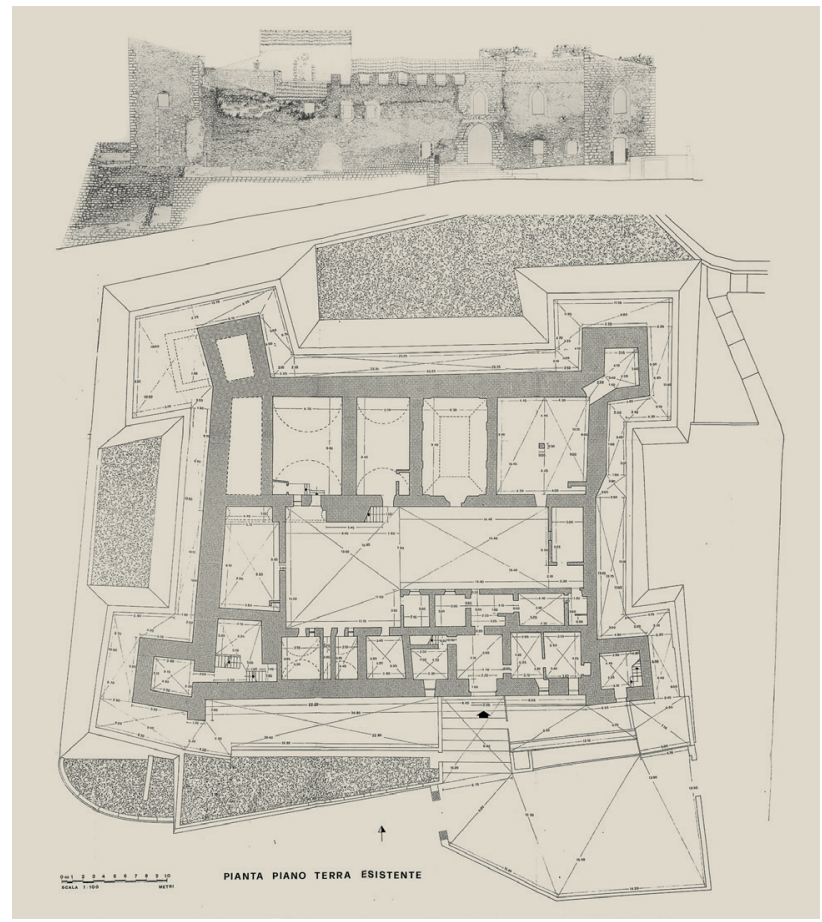

Figure 3. The first 'direct' survey of the castle (La Morella \& Oliva, 1980)

and passive (digital photogrammetry) sensors. The metric and material capture phase was preceded by the establishment of a closed polygonal topographic network, with about twenty vertices, measured by total station. Some forced centring were done. By ensuring the interchangeability between the signal and the instrument, they reduced the indeterminacy to about $1 \mathrm{~mm}$.

The resolution of the hyper-determined equations of the network (for the excess of angle and distance measurements) was carried out using least square adjustment software. From the vertices of the network, through forwarding intersections and distance measurements, the coordinates of the centre of the targets positioned on the surfaces and the pavement (about fifty) were acquired. The vertices, well placed in their spatial distribution, became the reference system made up of both GPC (Ground Constraint Points) for scaling the virtual models and QCP (Quality Control Points) 

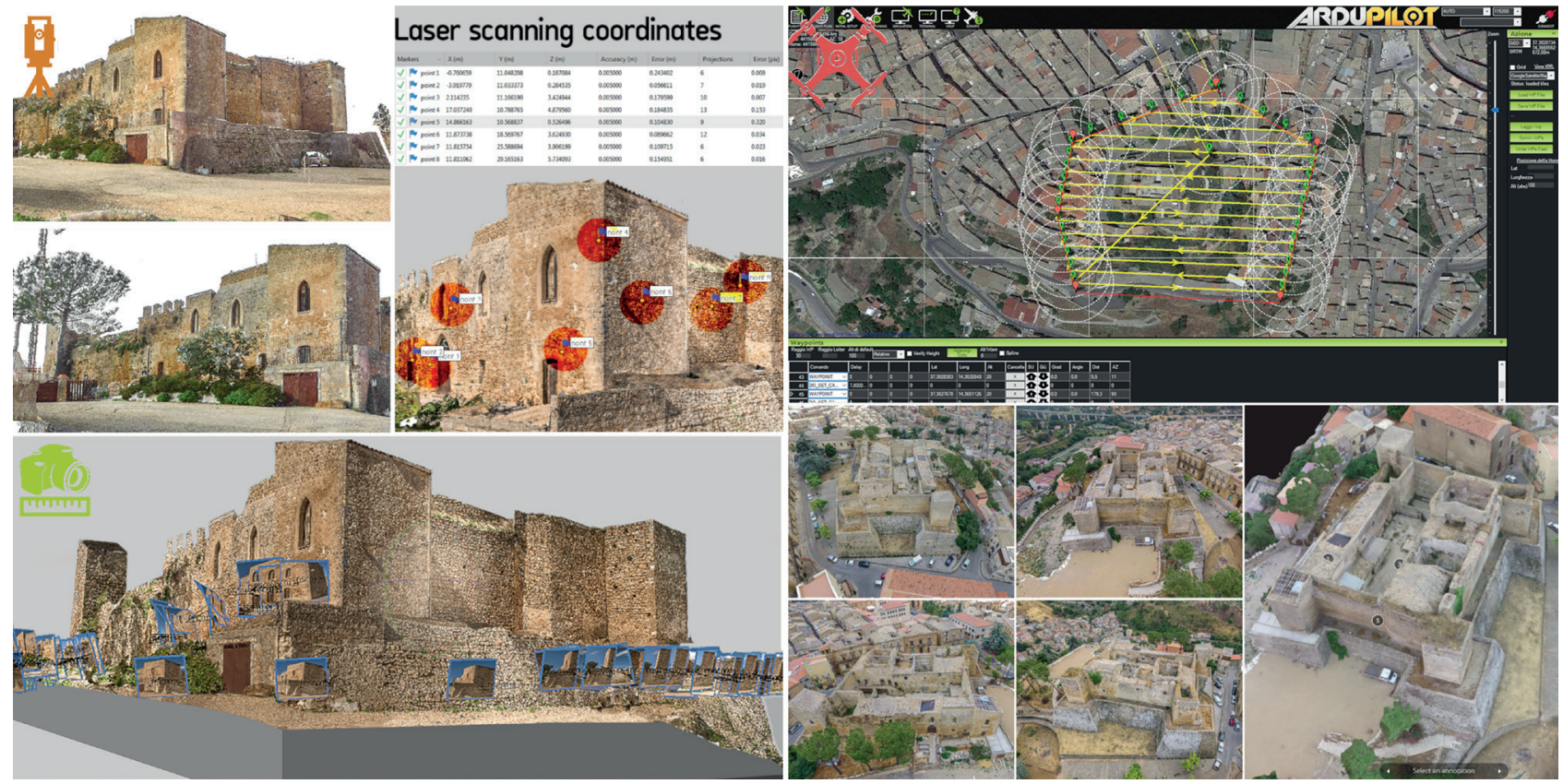

Figure 4. 3D survey: laser scanning and digital photogrammetry

for the accuracy check.

The topographic network has also made it possible to stiffen the global point cloud obtained from the multiple scans made from room to room, along the outer perimeter of the walls and the walkway, and on the roofs when accessible and practicable. Faro ${ }^{\circledR}$ technology was used both to data capture (3D Focus $\mathrm{S} 150$ laser scanner) and processing (Scene 7.0 software).

The overall cloud quality benefited from an initial alignment of the individual scans and thus an approximation of the different parts using image recognition algorithms. The use of external references - such as spheres and checkerboards - ensured a more rigid alignment of scans. It also made it possible to verify the inaccuracies according to the differences between the laser scanner measurements and the position of the topographical network vertexes. The ATS ${ }^{\circledR}$ Quality Manager - a plug-in to Faro $\AA$ Scene software - has been employed to improve accuracy in scans registration. The excellent overlap of the individual clouds was thus observed with an average approximation contained within the instrumental precision $(1.5 \mathrm{~mm})$. The single scans, after noise reduction and sampling to remove overlapping areas, allowed to obtain a discontinued model exported in e 57 format.

The photogrammetric process began with the acquisition of images, both terrestrial by a Canon $\AA 5$ D Mark II full-frame camera and $24 \mathrm{~mm}$ optics, and aerial by the DJI ${ }^{\circledR}$ Phantom 4 PRO UAV system with a 1-inch 20 mega-pixel CMOS camera. The camera was mounted on a tripod to define an inclined grip axis of about $45^{\circ}$; the camera was moved for parallel motions with overlapping values between 0.65 and 0.80 . The acquisition occurred in both directions from the ground level. Additional detailed images were acquired from different angles depicting the perimeter, which is the most complex part under the geometric aspect. The gripping axis tilt to surface normal scan determines a variable ground sampling distance (GSD) value. A minimum GSD of $5 \mathrm{~mm}$ has been ensured for each image. The flight was planned using the DJI ${ }^{\circledR}$ Terra software, an application capable of generating flight paths on GPS waypoints and setting parameters such as altitude, speed, inclination angle and camera shooting sequence. In particular, stripes were made (with overlapping images between $60 \%$ and $75 \%$ ) with two flight planes, at 20- and 50-meters average altitudes. Each swipe was repeated three times: the first with a vertical camera and the following two with a camera inclined at $45^{\circ}$ (for an average altitude of $20 \mathrm{~m}$ ) and $30^{\circ}$ (for an average altitude of $50 \mathrm{~m}$ ). The minimum GSD value, in this case, was above $10-15 \mathrm{~mm}$. The quality of the images, due to the sensor and the vibrations of the flight, was also lower than that of the images taken from the ground.

The photogrammetric 3D models were obtained by processing the photo capture sets according to the following workflow. The first phase saw the recognition, by the software, of specific points in the photographs than their later combination among the homologous frames. Based on this guidance, $3 \mathrm{DF}{ }^{\circledR}$ Zephir continued to operate the spatial positioning of the cameras and the subsequent generation of sparse clouds. The next steps involved the construction of the dense cloud, the conversion of the discontinuous point model into the continuous mesh model and, finally, the reprojection on the faces of the individual triangles of the RGB images (after an accurate blending to ensure uniformity of exposure and colour).

The final merging of the 3D laser scanner cloud and the photogrammetry mesh (Figg. 5-6), always carried out within the 3DF® Zephir workspace, allowed to generate a final model characterised by both a great metric accuracy and colour quality. This facilitated a very detailed analyses and the overall reinterpretation of the building, both from a geometric and material point of views.

\subsection{Analyses, critical interpretations and new findings}

Although dating back to the end of the $14^{\text {th }}$ century, the fortress recalls - from a typological and constructive point of view - the numerous castles built by Frederick II, Holy Roman Emperor and King of Sicily. The pure and regular volumes and the presence of large surfaces without openings, typical of the Swabian noble buildings, confirm its pre-eminently military character.

Its plan is rectangular with four towers arranged at the corner of the structure and an internal courtyard. The towers are no longer soaring above the height of the walls, but as it can be seen from some interruption marks at the top of the masonry and the comparison with historical iconography, the current height is certainly lower than the original one. The east and west sides are made up of high walls that do not show that they have hosted closed environments or spaces. However, the signs of a probable patrol walkway connecting the northeast and southeast towers 

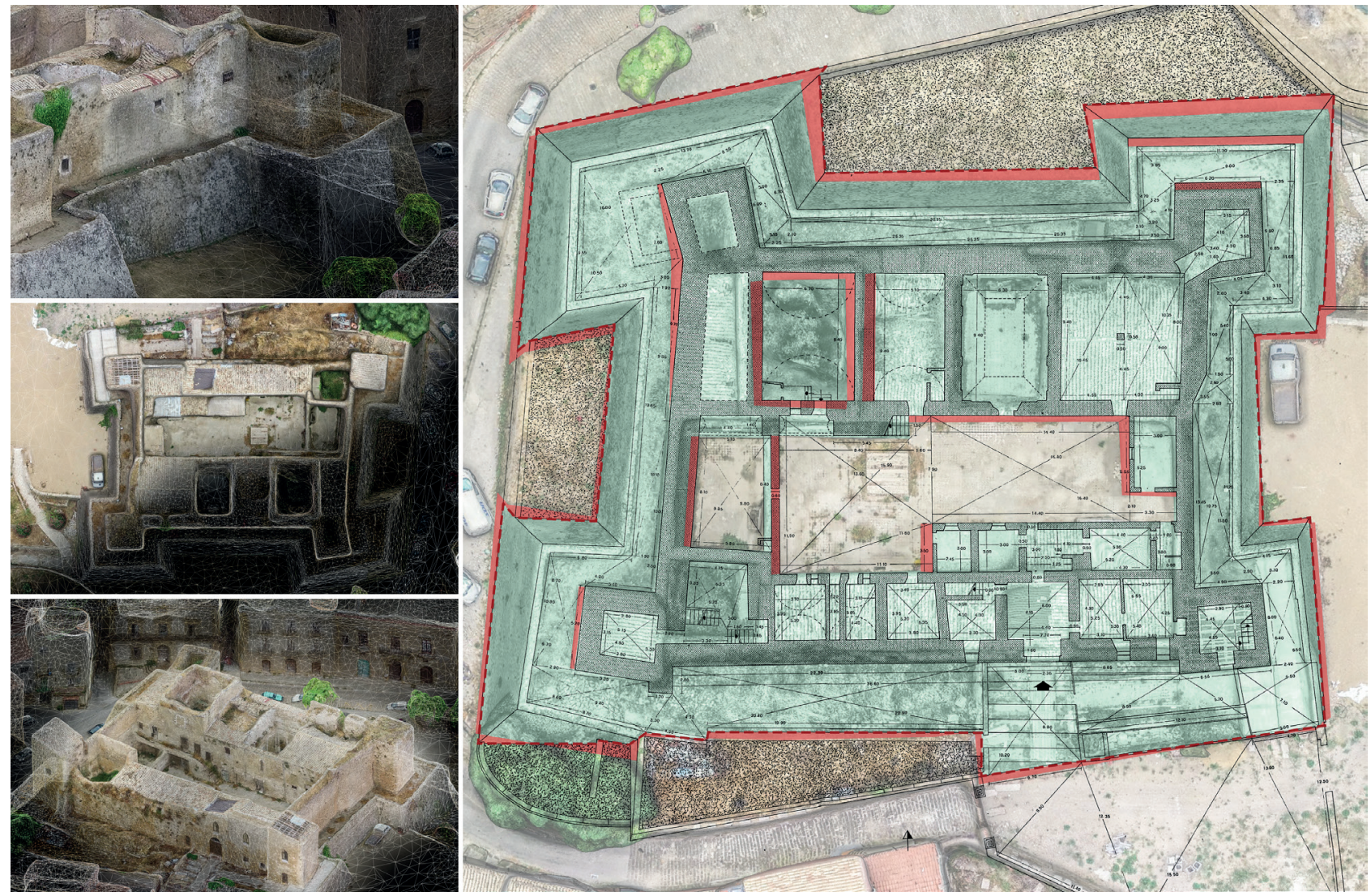

Figure 5. 3D reconstruction: final merging of the 3D laser scanner's cloud and the photogrammetry's model

can be found on the top of the walls of the east partition. The interiors are located in the northern and southern portions; they have probably been much reworked especially during the $19^{\text {th }}$ and $20^{\text {th }}$ centuries when the castle was used as a prison.

The southern body, which in the central part presents the access to the castle, is spread over two elevations. On the ground floor, in addition to the entrance hall leading to the courtyard, there are two vaulted rooms used as prison cells, accessible from the internal courtyard. Furthermore, there is a compartment containing the staircase and a block built with a single elevation that protrudes towards the court and constitutes an added part serving the penitentiary function. From the rooms of the first level of the southern portion, it is possible to go in the two towers located at the east and west ends. Another entrance to the eastern tower consists of a door accessible from the external walkway.

The northern portion of the castle has a rectangular layout with a wider cross-section than the rooms located to the south (about $11.50 \mathrm{~m}$ compared to $6.80 \mathrm{~m}$ ). Although with cautious uncertainty, it can be assumed that this part of the castle was built starting from the church of the previous Franciscan coenobium. The presence of the Order of Friars Minor in Piazza is documented around 1261 by the papal diplomacy (Bresc-Bautier, 1973); in 1318 , they obtained the land to build their convent (Cagliola, 1644; 1984). It can therefore be assumed that in the period in which the construction of the castle is traced back (Nigrelli, 1983) - the pre-existing ecclesiastical structure was not completely obsolete, having been built only 80 years earlier. It thus seems improbable that the construction of the castle was preceded by the demolition of the walls recently constructed.

From the analysis of the masonries of this part of the castle emerges the presence of two narrow windows with pointed arches one of which is closed - facing the internal courtyard. Together with the pointed arch of the eastern wall of the prison's chapel - currently clearly legible due to the fall of the plaster - and the particular protrusion found on the eastern external side of the structure - which suggests the presence of an apse - these elements indicate that this part of the castle probably belongs to the Franciscan church. As the recently discovered impost of the pointed arch suggests, the original pavement level approximately was 6 or $7 \mathrm{~m}$ below. It is plausible that the current level of the ground floor dates back to a filling operation that took place at the time of construction of the battered (sloping) face at the base of the whole castle. It is interesting to note that, in the context of previous studies, these elements have not been taken into consideration, so a priori excluding the hypothesis of permanence of the ancient Franciscan building.

Another important architectural feature in the north wing is a slightly higher structure situated on the west side. The complex stratigraphy in legible masonry in the rooms concerned suggests that radical changes affected this part of the building. In particular, the red colour of the sandstone, in the upper parts of the inner masonry, testifies to the consequences of a fire. However, there are here some architectural elements - such as the signs of quoins made of large blocks of sandstone and the presence of elegant mullioned windows in white limestone - which allow us to identify it as the seat of the baronial residential rooms.

Careful analyses carried out on the walls revealed a complex stratigraphy characterized by several masonry typologies. The castle is almost entirely made up of masonries made with local sandstone and bedding mortar, which provide its characteristic yellow ochre tones. There is also the presence of light grey calcareous wall elements, such as the aforementioned arch in the chapel, as well as the mullioned windows and the two openings with pointed arch, both facing the south side of the internal courtyard. This stone is the same used in the $15^{\text {th }}$ century Catalan Gothic buildings of Piazza Armerina, such as the bell tower of the cathedral. In the inner courtyard, a portion of the cement plaster - that most probably covered the whole walls when the complex was used as 

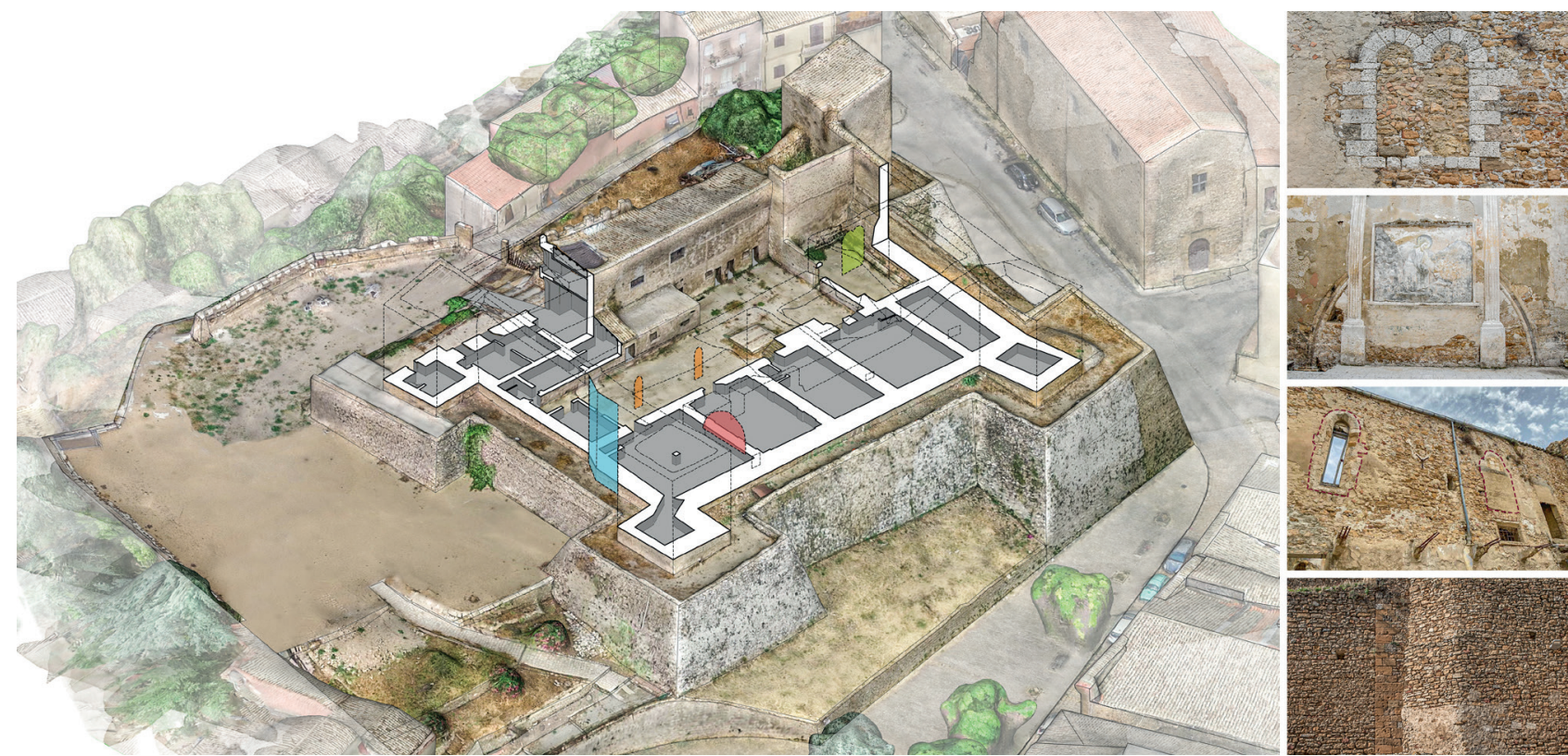

Figure 6. Axonometric cross section of the final model

a prison - is still visible.

Masonries textures vary and are characterized by stone blocks of different sizes, squared in some parts, shapeless in others and arranged in regular, almost regular or disordered rows. In some parts, it is equally evident that they are reinforced by stones and/ or brick fragments (Figg. 7-8). The signs of the invasive transformations that took place in the $19^{\text {th }}$ and $20^{\text {th }}$ centuries, such as wall additions, construction of walkways and brackets in reinforced concrete, added volumes in the courtyard space, structural consolidations with iron chains, presence of plant components such as iron and plastic pipes and electrical cables, are evident.

\subsection{Current state and proposals for conservation and reuse}

Since 1974, the monuments was gradually abandoned. As shows by the 1980's architectural survey, the structure still had all the wooden roofs covered with Sicilian tiles. However, the collapse of most of them and certain floors are documented in 20002004's studies. The new survey has assessed that the castle is in a somewhat compromised state of preservation. In general, we can distinguish the typical decay phenomena of historic buildings located in open, unused places and in contact with atmospheric agents, as well as the absence of large portions of the roofs. The advanced state of instability constitutes an important obstacle to the safe fruition of the whole property.

The design of the activities to be implemented for the conservation and enhancement of the Aragonese castle will have to relate to historical, critical and architectural data, especially taking into account the new evidences that emerged from this preliminary study. Appropriate investigations are still required to shed light on certain assumptions that are not sufficiently supported by documentary sources.

The conservation project must therefore comprise coordinated interventions based on the elements and materials constituting the castle. The main purpose is to preserve the artefact and the readability of the complex stratigraphy of its masonries, so ensuring its transmission tu future generations. Besides preservation of stone surfaces - i.e. consolidation, cleaning and protection interventions - special attention should be paid to the reconstruction of the roofs that are almost totally missing or in an advanced state of instability.

As already mentioned, the local community strongly perceives the monument's identity as reflected in the wide participation in the latest FAI-led promotional initiatives. This suggests the need for enhancement and re-functionalization actions that would respectfully exploit the potential of the building itself - including

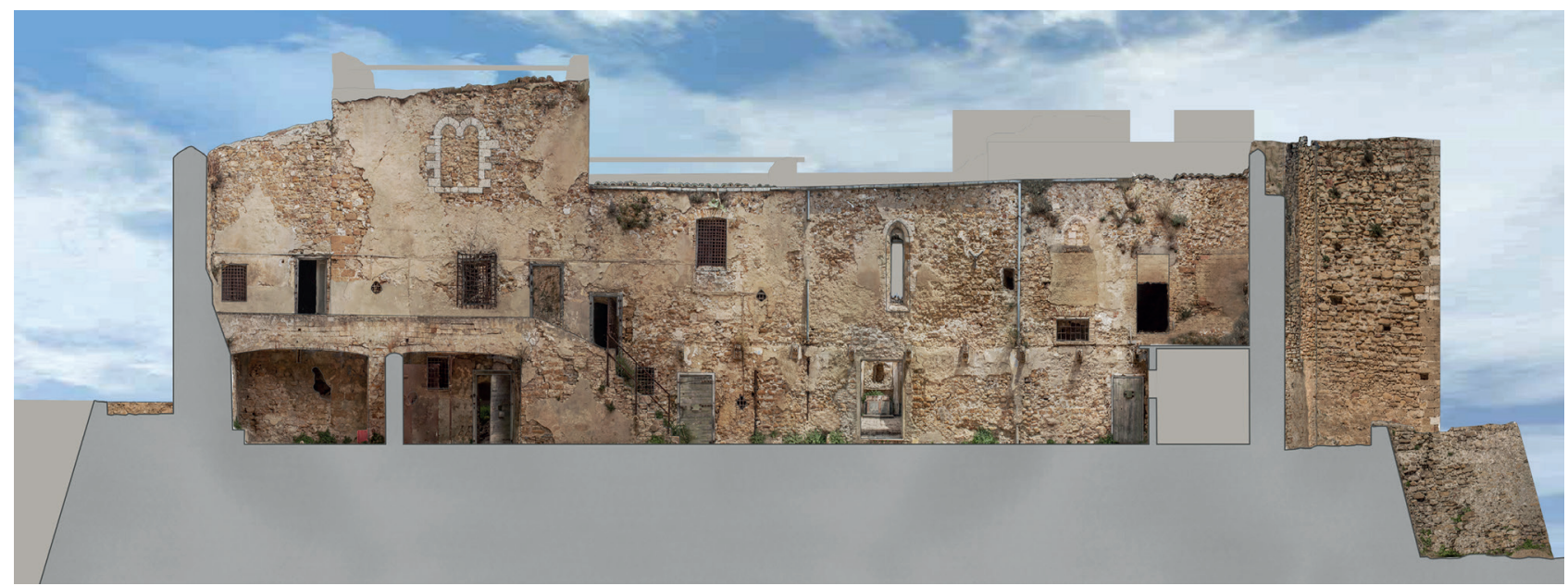

Figure 7. Othographic projection of the courtyard's E-W wall 


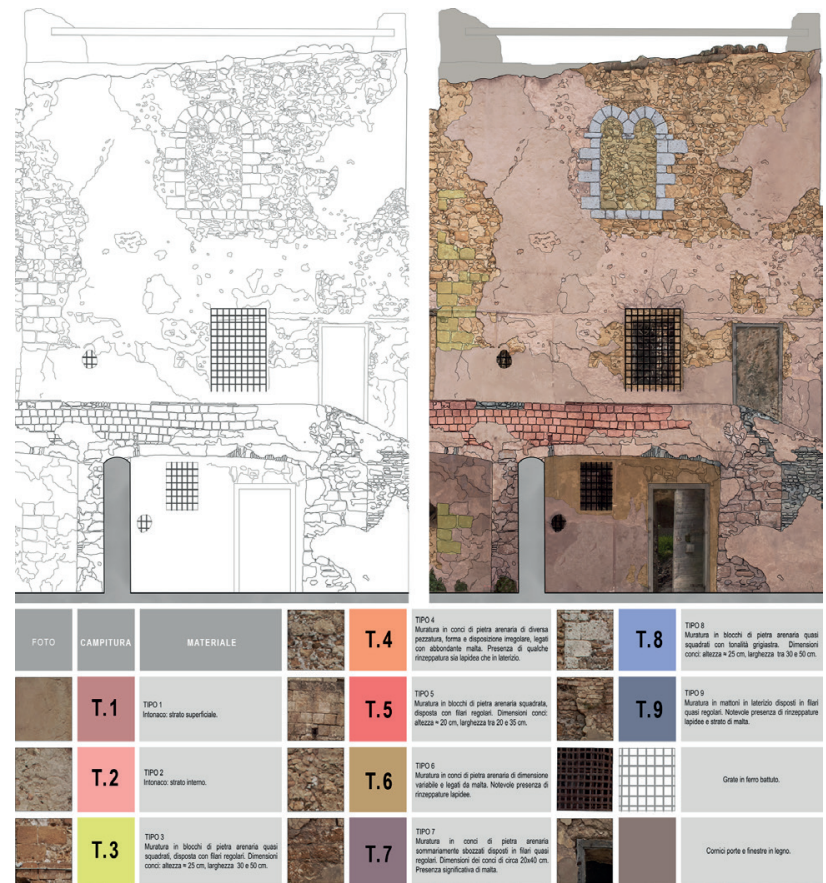

Figure 8. Analysis and characterisation of masonry walls

the close connection and easy accessibility of the evocative historic centre of the city. Interventions designed to include new compatible functions, to revitalise a representative monument of both the history of the city and Sicilian fortified architecture.

\section{CONCLUSIONS}

Aragonese Castle is an essential landmark of Piazza Armerina. It embodies cultural assets and testimonies that need to be rediscovered and valued. Although unused for some time, the manor now benefits from the great attention of a new owner, both sensitive to its protection and aware of its role of guardian of a property belonging to the community. It is an architectural work that deserves to be made public through conscious and conscientious interventions carefully planned and conducted without improvisation, with the necessary progressiveness and 'slowness'.

The study undertaken intends to be an example of best practice for 3D documentation for the knowledge and improvement of the fortresses of Sicily. A heritage that is often affected by disrespectful actions or even abandoned.

In our days, the ease of access to information and increasingly user-friendly technology have made it possible to speed up the phases of survey and understanding of buildings. However, at the same time, it has too often led to the production of low-quality works. It is, alas, an increasingly frequent practice to base historical and iconographic research on the internet (cut and paste of documents rewritten and adapted for popular use), without carrying out a critical reflection and a preliminary sources' checking. Unfortunately, there is a widespread idea that it is enough to fly a drone or press the button of an instrument to automatically obtain virtual models without the use of control points for checking errors.

The survey was, and still is today, a complex practice that must be carried out by competent people both trained on modern digital technologies and aware of surveying and restoration principles. An 'art' that needs to be learned within universities and specialized schools through an interdisciplinary approach capable of combining architecture and engineering, conservation theories, photographic techniques and knowledge of flight, computer science and aerodynamics.
The pandemic delayed the second phase of the diagnostic investigation, aimed at searching for evidence hidden under the flooring or behind the plaster of the structures. In particular, new activities have been planned; they will use electromagnetic instrumentation and georadar to identify underground rooms, as well as thermographic investigations to bring to light ancient openings today buffered. An activity that we hope to continue shortly.

\section{ACKNOWLEDGEMENTS}

Authors would like to thank the castel's owner, Dr. Giancarlo Scicolone and Dr. Salvatore Lo Re for their support to this research. Research activities were directed by AC and AV. The editorial responsibility of this essay is as follows: the introduction, the paragraph 2.2 and the conclusions are due to $\mathrm{AV}$; paragraph 2.1 and 3.3 to LRF; paragraph: 3.1 and 3.2 to $\mathrm{AC}$; paragraph 3.4 to MR.

\section{REFERENCES}

Amico, V., 1859. Dizionario topografico della Sicilia, tradotto dal latino e continuato sino ai nostri giorni per Gioacchino Di Marzo, II. Di Marzo editore, Palermo.

Bonifazio, A., 1950. Chiesa di S. Francesco d'Assisi di Piazza Armerina, Tipografia Bologna, Piazza Armerina, 5-6.

Bresc, H., Maurici, F., 2009. I castelli demaniali della Sicilia (secoli XIII-XV) in Panero F., Pinto G., Castelli e fortezze nelle città italiane e nei centri minori italiani (secoli XIII-XV). Centro Internazionale di Ricerca sui Beni Culturali, Cherasco, 271-317.

Bresc-Bautier, G., 1973. Bulles d'Urbain IV en faveur de l'Ordre du Saint-Sépulchre (1261-1264). Mélanges de l'École Française de Rome. Moyen Âge-Temps Modernes, 85, 1973, 283-310.

Cagliola, F., 1644. Almae Siciliensis provinciae minorum conventualium S. Francisci Manifestationes novissimae sex explorationibus complexae (reprint 1984). Rotolo, F, Officina di Studi Medievali, Palermo.

Caruso, E., Nobili, A., 2001. Le mappe del catasto borbonico di Sicilia. Territori comunali e centri urbani nell'archivio cartografico Mortillaro di Villarena (1837-1853). Regione Siciliana, Palermo.

Maurici. F., 2020. Castelli medievali in Sicilia: da Carlo d'Angiò al Trecento. Kalos, Palermo.

Nigrelli, F.C., 2019. Lo spazio perduto: trasformazioni urbane e modernizzazione a Piazza Armerina nel XIX secolo. Franco Angeli, Milano.

Nigrelli, I., 1983. Piazza Armerina medievale. Electa, Milano.

Pappalardo, L., 1882., I monumenti di Piazza Armerina per l'Ingegnere Luigi Pappalardo. Tipografia Pansini, Piazza Armerina.

Roccella, A., 1890. Storia di Piazza: chiese, conventi e istituti di filantropia in Piazza, III.. Unpublished manuscript. Municipal Library of Piazza Armerina.

Versaci, A., Fauzìa, L. R., Russo, M., Cardaci, A. 2020. The integrated fast survey for the risk assessment: a proposal for the safeguarding of the medieval castles in central Sicily, Int. Arch. Photogramm. Remote Sens. Spatial Inf. Sci., XLIV-M-1. 893-900. 